\author{
Michael Bratychak, Taras Chervinskyy, Olena Astakhova \\ and Olena Shyshchak
}

\title{
BITUMEN PRODUCTION VIA TAR OXIDATION IN THE PRESENCE OF PETROLEUM RESIN WITH FLUORINE-CONTAINING GROUPS
}

\author{
Lviv Polytechnic National University, \\ 12, St. Bandera str., 79013 Lviv, Ukraine \\ mbratych@polynet.Iviv.ua
}

Received: July 06, 2010 / Revised: August 18, 2010 /Accepted: October 6, 2010

(C) Bratychak M., Chervinskyy T., Astakhova O., Shyshchak O., 2010

\begin{abstract}
The tar oxidation process has been studied at $523 \mathrm{~K}$, air flow rate of $2.0 ; 2.5$ and $5.0 \mathrm{~h}^{-1}$ and process time of 6,9 and $12 \mathrm{~h}$ in the presence of 2.5; 5.0 and 7.5 mas \% (to calculate for the raw material)of petroleum resin with fluorine atoms. The tar is the residue of black oil vacuum distillation obtained from the oils of Western-Ukrainian fields. The effect of process conditions on the characteristics of obtained bitumen has been determined. The structural-group composition of blown bitumen has been examined.
\end{abstract}

Keywords: tar, bitumen, oxidation, petroleum resin, penetration, ductility, softening temperature, adhesion, structural-group composition.

\section{Introduction}

Petroleum bitumens are widely used in production of pavements [1,2], waterproofers [2], anticorrosive coats [3], filling resins [2] etc. [4, 5]. One of their production methods is the oxidation of petroleum residues, namely tars, by air oxygen without a catalyst at 503-573 K [1].

The amount of chemically bound oxygen in the blown bitumen increases with the increase of aromatic hydrocarbons content in the raw material. Moreover, the presence of fractions boiling away till $773 \mathrm{~K}$ in the amount of 10 mas \% and more in the petroleum residue used for bitumen production affects the oxidation process negatively [6]. The air supply to raw material increases the content of solid resins and asphaltenes, and at the same time decreases the oils amount. The formation of carbenes and carboides becomes noticeable at asphaltenes concentration of 35-40 mas \% [6].

The main factors affecting the tar oxidation are: nature of raw material; tar softening temperature; content of oils, paraffin and naphthenic compounds, asphaltenes in tar; process time and temperature; air flow rate [4]. At the same time the blown bitumens obtained via oxidation of petroleum residues sometimes have bad operational performances. Moreover, bitumen cannot be obtained from arbitrary raw material. Therefore, modifiers are often used for improving operational performance of commercial bitumens [7]. Polymers are the mostly used as modifiers and bitumen characteristics are improved due to the preparation of bitumen-polymeric mixtures [7-9]. If we apply such modification method, the elemental sulfur is used as a modifier before oxidation of petroleum residue [10]. The introduction of sulfur in the amount of 2 5 mas \% at 393-403 K into the blown bitumen increases its heat resistance.

Another modification method uses petroleum resins obtained via cooligomerization of unsaturated compounds presented in the $\mathrm{C}_{9}$ fraction, which is the by-product of ethylene production [11, 12]. Such resins may be also used for preparation of bitumen-polymeric mixtures.

The experiments concerning the development of petroleum resins with functional end-groups on the basis of the $\mathrm{C}_{9}$ fraction are carried out in Lviv Polytechnic National University [13-18]. Such resins are used both as bitumen modifiers at tar oxidation [19] and for preparation of bitumen-polymeric mixtures [20]. In order to extend the range of functional groups presented in petroleum resins we synthesized resins with fluorine atoms at the Department of Chemistry and Technology of Petroleum. This work deals with the investigation of results concerning the possibility of using petroleum resins with fluorine atoms as modifiers at bitumen production via tar oxidation.

\section{Experimental}

\subsection{M aterials}

Used tar is a residue of black oil vacuum distillation obtained from the oils of Western-Ukrainian fields. It was run off at the unit of JSC "Naftokhimik Prykarpattya" 
(Nadvirna, Ukraine) with the following characteristics: penetration $-188.01 \mathrm{~mm}$; ductility $-13.3 \mathrm{~cm}$; softening temperature by "ring and ball" method $-313.5 \mathrm{~K}$.

Petroleum resin with fluorine atoms (PRF) was synthesized from pyrocondensate of the $\mathrm{C}_{0}$ fraction. The peroxy derivative of ED-24 epoxy resin (FPO) was used as an initiator. ED-24 with fluorine atoms was synthesized by the procedure described in [21]. $500 \mathrm{~g}$ of the $\mathrm{C}_{9}$ fraction and $25 \mathrm{~g}$ of FPO dissolved in $50 \mathrm{ml}$ of acetone were loaded into an autoclave. The autoclave was placed into the thermostat and heated at $403 \mathrm{~K}$ for $40 \mathrm{~h}$. Then the autoclave was cooled to the room temperature and the obtained mixture was distilled. During vacuum distillation two fractions were run off: one - at the boiling temperatures of 323-353 K and atmospheric pressure and the second one - at the boiling temperatures of $353-446 \mathrm{~K}$ and residual pressure of 7-10 $\mathrm{mm} \mathrm{Hg}$. The vat residue was PRF of dark-brown colour with the molecular mass of $1000 \mathrm{~g} / \mathrm{mol}$.

\subsection{Procedure of Tar Oxidation}

Tar was oxidized at the laboratory plant, the scheme of which is given in [20]. $100 \mathrm{~g}$ of the mixture consisting of tar and PRF with a definite ratio were loaded into the reactor. Then the reactor electric heating was switched on and the air was supplied at the temperature 5 degree lower than the necessary one. The air flow rate was controlled by a flowmeter. After the process finished the air supply was stopped and the obtained bitumen was poured into the vessel. The softening temperature, ductility and "adherence with glass" were determined.

\subsection{Analysis Procedure}

The bitumen softening temperature was determined using "ring and ball" method [22], ductility and penetration - using the method described in [22], "adherence with glass" - [4]. The content of asphaltenes, neutral resins and oils was determined using the procedure described in $[23,24]$.

\section{Results and Discussion}

The process of tar joint oxidation in the presence of PRF was studied by the procedure described in Subsection 2.2. The PRF amount was 5 mas \% of the initial tar amount. Tar oxidation without PRF was studied for the comparison. The bitumen was modified at $523 \mathrm{~K}$ for $6 \mathrm{~h}$. The air flow rate was $2.5 \mathrm{~min}^{-1}$. The experimental results are represented in Table 1.

Comparing the characteristics of blown bitumen with PRF and without it, one can see that the introduction of the resin in the amount of 5 mas \% increases the bitumen ductility in 4 times, and slightly increases the softening temperature and penetration.

Bitumen characteristics

\begin{tabular}{|c|c|c|c|}
\hline \multirow{2}{*}{ Raw material } & \multicolumn{3}{|c|}{ Bitumen characteristics } \\
\cline { 2 - 4 } & $\begin{array}{c}\text { Penetration } \\
\text { at } 298 \mathrm{~K}, 0.1 \mathrm{~mm}\end{array}$ & $\begin{array}{c}\text { Ductility } \\
\text { at } 298 \mathrm{~K}, \mathrm{~cm}\end{array}$ & $\begin{array}{c}\text { Softening } \\
\text { temperature, } \mathrm{K}\end{array}$ \\
\hline Tar without PRF & 115 & 21,8 & 313,0 \\
\hline Tar +PRF & 116 & 62,3 & 318,8 \\
\hline
\end{tabular}

Process conditions and characteristics of modified bitumen

\begin{tabular}{|c|c|c|c|c|c|c|}
\hline \multicolumn{3}{|c|}{ Process conditions } & \multicolumn{4}{c|}{ Bitumen characteristics } \\
\hline $\begin{array}{c}\text { PRF amount, } \\
\text { mas \% to calculate } \\
\text { for the initial tar }\end{array}$ & $\begin{array}{c}\text { Air flow } \\
\text { rate, } \mathrm{h}^{-1}\end{array}$ & $\begin{array}{c}\text { Oxidation } \\
\text { time, } \mathrm{h}\end{array}$ & $\begin{array}{c}\text { Penetration } \\
\text { at } 298 \mathrm{~K}, \\
0.1 \mathrm{~mm}\end{array}$ & $\begin{array}{c}\text { Ductility at } \\
298 \mathrm{~K}, \mathrm{~cm}\end{array}$ & $\begin{array}{c}\text { Softening } \\
\text { temperature, } \mathrm{K}\end{array}$ & $\begin{array}{c}\text { Adhesion, } \\
\%\end{array}$ \\
\hline 2.5 & 2.5 & 6 & 117 & 30.5 & 319.2 & 57.0 \\
\hline 5.0 & 2.5 & 6 & 116 & 62.3 & 318.8 & 64.7 \\
\hline 7.5 & 2.5 & 6 & 95 & 37.2 & 316.2 & 71.5 \\
\hline 5.0 & 2.0 & 6 & 130 & 39.4 & 317.6 & 43.8 \\
\hline 5.0 & 3.0 & 6 & 115 & 62.3 & 319.0 & 64.9 \\
\hline 5.0 & 2.5 & 9 & 93 & 43.2 & 322.3 & 71.2 \\
\hline 5.0 & 2.5 & 12 & 42 & 39.7 & 325.1 & 78.3 \\
\hline
\end{tabular}

Note: oxidation temperature is $523 \mathrm{~K}$ 
Structural-group composition of modified blown bitumen

\begin{tabular}{|c|c|c|c|c|c|}
\hline \multicolumn{2}{|c|}{ Process conditions } & \multicolumn{3}{c|}{ Content of, mas \% } \\
\hline $\begin{array}{c}\text { PRF amount, } \\
\text { mas \% to calculate } \\
\text { for the initial tar }\end{array}$ & $\begin{array}{c}\text { Air flow rate, } \\
\mathrm{h}^{-1}\end{array}$ & $\begin{array}{c}\text { Oxidation } \\
\text { time, } \mathrm{h}\end{array}$ & oils & resins & asphaltenes \\
\hline 0 & 2.5 & 6 & 58.1 & 30.2 & 11.5 \\
\hline 2.5 & 2.5 & 6 & 50.0 & 28.1 & 21.7 \\
\hline 5.0 & 2.0 & 6 & 55.3 & 24.0 & 20.6 \\
\hline 5.0 & 2.5 & 6 & 41.3 & 22.2 & 36.0 \\
\hline 5.0 & 2.5 & 12 & 40.2 & 28.9 & 30.5 \\
\hline 5.0 & 3.0 & 6 & 54.4 & 23.5 & 21.5 \\
\hline 7.5 & 2.5 & 6 & 51.6 & 26.4 & 22.0 \\
\hline
\end{tabular}

Note: oxidation temperature is $523 \mathrm{~K}$

In order to establish the optimum concentration of PRF in the raw material we studied different ratio tar:PRF at tar joint oxidation in the presence of resin under abovementioned conditions (Table 2).

One can see from Table 2 that the increase of PRF amount in the initial mixture from 2.5 to 5.0 mas \% increases the values of penetration and ductility of modified bitumen. At the same time adhesive properties of the obtained bitumen are also increased but the softening temperature remains almost the same. The increase of PRF amount from 5.0 to 7.5 mas \% decreases the abovementioned values except for adhesion. Adhesive properties of the obtained bitumen are better at greater amount of PRF. So, comparing results given in Tables 1 and 2, we can consider 5 mas $\%$ of the modifier as the optimum amount. The greater amount does not give desired results and it is inexpedient.

Taking into account that the air flow rate affects the process intensity and the properties of blown bitumen we examined its effect on the characteristics of obtained products (Table 2). Under above-mentioned optimum conditions (temperature $523 \mathrm{~K}$, time $6 \mathrm{~h}$, PRF amount 5 mas \%) the air flow rate was changed from 2.0 to $3.0 \mathrm{~h}^{-1}$. Results from Table 2 show that the increase of air flow rate to $3.0 \mathrm{~h}^{-1}$ increases the ductility to $62.3 \mathrm{~cm}$. At the same time the penetration decreases to $115.0 .1 \mathrm{~mm}$. It indicates the increase of bitumen hardness. The adhesive properties are also better.

Oxidation time is also among the factors affecting the process (Table 2). The increase of oxidation time from 6 to $12 \mathrm{~h}$ increases the softening temperature from $318.8 \mathrm{~K}$ to $325.1 \mathrm{~K}$. However, the penetration decreases sharply, the same as ductility does. The value of "adherence with glass" increases indicating the improvement of adhesive properties of modified bitumen. The explanation of obtained results is as follows. The first stage of oxidation is conversion of oil components into resins with a higher ductility. At the increase of process time the formed resins are further converted into asphaltenes resulting in the decrease of bitumen ductility.

We examined structural-group composition of modified blown bitumens (Table 3 ) for confirming the above-noted considerations.

The results of Table 3 confirm the oil conversion into resins and later on in asphaltenes. Such conversion gives the possibility to improve operational performance of obtained modified bitumens.

Thus, the optimum parameters of tar joint oxidation in the presence of PRF are: temperature $-523 \mathrm{~K}$, process time $-6 \mathrm{~h}$, air flow rate $-2.5 \mathrm{~h}^{-1}$, PRF amount -5 mas $\%$ to calculate for the raw material. The bitumen obtained under such conditions has satisfactory operational performances.

\section{Conclusions}

The obtained results show the advisability of using petroleum resin with fluorine-containing groups as the additive to the tar with the aim of production of bitumen with satisfactory operational performances. The amount of resin should be 5 mas \% to calculate for the initial tar. The process should be carried out at $523 \mathrm{~K}$ for $6 \mathrm{~h}$ with the air flow rate of $2.5 \mathrm{~h}^{-1}$. Petroleum resins with fluorinecontaining groups favor the oils conversion into resins and asphaltenes which are responsible for operational performances of blown bitumen.

\section{References}

[1] Grudnikov I.: Proizvodstvo Neftyanykh Bitumov. Khimiya, Moskwa 1983.

[2] Kotov S., Starov D., Morozov V. et al.: Neftepererabotka i Neftekhimiya, 2003, 7, 38.

[3] Kemalov R., Stepin S., Kemalov A. et al.: Khim. i Techn. Topliv i Masel, 2003, 5, 36.

[4] Hoon R.: Neftyanye Bitumy. Khimiya, Moskwa 1973. 
[5] Kut'in Yu., Blohinov V., Lagutenko N. et al.: Neftepererabotka i Neftekhimiya, 2002, 11, 16.

[6] Belokon' N., Kompaneec V., Kolpakova N. et al.: Neftepererabotka i Neftekhimiya, 2001, 1, 19.

[7] Korobkova V. and Aleksandrova S.: Neftepererabotka i Neftekhimiya - Problemy i Perspektivy, Ufa 2001, 75.

[8] McNally T., Fawcett A. and McNally G.: Plast., Rubber \& Compos., 2000, 7, 385.

[9] Titova T. and Aminov A.: Khim. i Techn. Topliv i Masel, 1992, 1,8.

[10] Kut'in Yu., Telyashev E., Vezirov R. et al.: Sborn. Nauchn. Trudov Instituta Problem Neftekhimpererabotki AN Bashkirstan, 2001, 33, 40.

[11] Dumskyi Yu.: Neftepolymernye Smoly. Khimiya, Moskwa 1988.

[12] Shamparov A. and Ermakov V.: Neftepererabotka i Neftekhimiya, 2002, 10, 27.

[13] Bratychak M., Gagin M., Shyshchak O. and Waclawek W.: Chem. i Inzyneria Ecologiczna, 2004, 11, 53.

[14] Bratychak M., Shyshchak O., Romashko I. et al.: Ecol. Chem. \& Eng., 2006, 13, 17.

[15] Bratychak M., Romashko I., Shyshchak O. et al:: ibid, 25.

[16] Bratychak M., Romashko I., Shyshchak O. et al.: Ecol. Chem. \& Eng., 2007, 14, 245.

[17] Bratychak M., Grynyshyn O., Shyshchak O. et al.: ibid, 225. [18] Bratychak M., Grynyshyn O., Astakhova O. et al.: Ecol. Chem. \& Eng., 2008, 15, 387.
[19] Grynyshyn O., Bratychak M., Krynytskiy V. and Donchak V.: Chem. \& Chem. Techn., 2008, 2, 47.

[20] Grynyshyn O., Astakhova O. and Chervinskyy T.: Chem. \& Chem. Techn., 2010, 4, 241.

[21] Bratychak M., Chervinskyy T., Shust O. and Shyshchak O.: ibid, 125 .

[22] Gosudarstvennye Standarty: Nefteprodukty. Masla. Smazki. Prysadki. Izd-vo standartov, Moskwa 1987.

[23] Diyarov I.: Khimiya Nefti. Khimiya, Leningrad 1990.

[24] Isagulyanc V. Khimiya Nefti. Khimiya, Moskwa 1965.

\section{ОДЕРЖАННЯ БІТУМІВ ОКИСНЕННЯМ ГУДРОНУ В ПРИСУТНОСТІ НАФТОПОЛІМЕРНОЇ СМОЛИ 3 ФЛУОРВМІСНИМИ ГРУПАМИ}

Анотація. Вивчено при 523 К, витраті повітря 2,0;

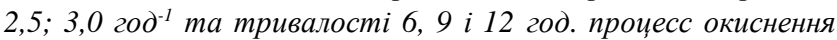
гудрону, який являє собою залишок вакуумної перегонки мазута, виділений з нафт західно-украӥнських родовищ, в присутності 2,5; 5,0; 7,5 \% мас. на вихіднусировинунафтополімерної смоли, що містить атоми флуору. Встановлено вплив умов проведення прочесуна характеристикумодифікованих бітумів та вивчений структурно-груповий склад окиснених бітумів.

Ключові слова: гудрон, бітум, окиснення, нафтополімерна смола, пенетрація, дуктильність, температура розм'якшення, адгезія, структурно-груповий склад. 